\title{
Local Regulation Cancellation Mechanism and its Legal Consequence based on Lex Superiori Deregot Legi Inferiori Principle in Economy
}

\author{
Asri Agustiwi ${ }^{1 *}$, Isharyanto $^{2}$, and Hartiwiningsih ${ }^{2}$ \\ ${ }^{1}$ Student of Law Science Doctoral Program, Sebelas Maret UniversitySurakarta, Indonesia \\ ${ }^{2}$ Faculty of Law, Sebelas Maret University, Surakarta, Indonesia
}

\begin{abstract}
This article addressed the local regulation cancelling mechanism and its legal consequence based on lex superiori derogat legi inferiori principle. The authorization of local area has contributed positively and negatively. Per June 2016, there have been 3,143 regulations voided or revised by Government including Local Government, Interior Ministry, and Governor: 111 Interior Minister's decrees and 1,267 Local Regulations or Local Leader Regulations at Regency/City level. This figure consisted of 1,765 Local Regulations or Local Leader Regulations at Regency/City level: 111 Interior Minister's Regulation or Decree and 1,267 Local Regulations or Local Leader Regulations at Regency/City level. The research method is normative juridical method involving document and regulations which related with the local regulation cancellation mechanism. Those data are sharpen with normative descriptive qualitative analysis. The result of research showed that legislator and drafter could not formulate a provision of Local Regulation freely but it should consider the higher legislations such as 1945 Constitution (thereafter called UUD 1945), Law, Government Regulation, and Presidential Regulation, and Local Regulation Cancellation can be made if the regulation disrupts concord between members of community, access to public service, public orderliness and composure, and economic activity to improve the people's wellbeing, and or results in discrimination against ethnic, religion and belief, race, inter-group, and gender.
\end{abstract}

\section{Introduction and Literature Review}

Autonomy is defined as a regulation developed by a distinctive or self-governing entity (government) [1]. In organizing autonomy, Local Regulation (peraturan daerah, thereafter called perda) is required, including both provincial and regency local regulations.

Local regulation or perda should be consistent with the condition of people (community) where it is enacted. As the organizer of local government, local government is required to understand the support and demand developing within society, but in fact after the enactment of a Perda, many substances of it are frequently considered as inconsistent with the people's

${ }^{*}$ Corresponding author: asritiwi26@gmail.com 
need. Considering this phenomenon, the limitation or restriction in the form of Local Regulation cancellation is necessary [2].

Constitution Court makes final decision (verdict) bonding the authority of executive review over Regency/City Local Regulation and Regent/Mayor Regulation. Verdict with a quo case registration number states that the formulation of article related to the authority of executive review is in contradiction with RI's 1945 Constitution (unconstitutional) and has no legal power underlying the judge in deciding the case related to the definition of local autonomy concept implementation in the context of unitary state [3].

The cancellation of 3,143 local regulations on June 13, 2016 generated reaction from many parties, because a Local Regulation inhibits investment and leads the people to be in trouble [4].

"In developed capitalist countries, the law is sustained through the interaction between agents, field, and the legislative authorities. The law is also a key institution to address contracting uncertainty. This is a part of the power structure, and a large community means by which power is exercised [5]. In Indonesian, there is a same but different concept because the local regulation is cancelled not due to the people's willingness or because it is in contradiction with the people's interest or power. Modern legal theories see the law solely from the viewpoint of the ruling class or, in the language of the Hartian, from external point of view. Why? because the law philosophers have implicitly received the law as the exclusive domain of Governments and partisan politics [6].

Following a qua verdict stipulating, the mechanism of executive review over Regency/City local legal product is an unconstitutional norm. Constitution Court issued Verdict Number 56/PUU-XIV/2016 [7] stipulating that the mechanism of executive review over provincial local legal product is also a norm of law in contradiction with the mandate of constitution [4].

It is in contrast to United Kingdom law in which "the functions of the Parliament and the courts in making the law and explaining how the law can be accessed and understood. the role of the judiciary in interpreting and advancing the common law, as well as dangers in seizing Parliament's role when doing his role then considered will have an impact on the jurisprudence of the European Court" [8].

This study will discusses many types of Local Regulation in Indonesia becoming the object of cancellation, causes of Local Regulation cancelation, the officers authorized to cancel, cancellation instrument, and consequence or sanction. Local regulations becoming the object of cancellation are: Provincial Local Regulation, Governor Regulation, Regency/City Regulation, and Regent/Mayor Regulation. In this article, Governor/Regent/Mayor regulations refers is called Perkada.

\section{Objective of the Study}

The objective of study is to analyze the mechanism of drafting Local Regulation in 3,143 local regulations in economy sector and the cancelation of Local Regulation and its legal consequence based on lex superiori derogat legi inferiori principle.

\section{Methodology}

The research method employed was juridical normative one with normative qualitative analysis technique based on secondary data and supported with primary data to sharpen the analysis in discussion. Normative law study is a law research conducted by studying literatures [9]. In normative writing, the type of data employed was secondary data collected through library study on Legislations, document, literature books, and etc relevant to the 
problem studied [10]. Normative descriptive law writing can be defined as a problem solving procedure studied by describing the condition of object or subject studied in present condition based on the actual fact. Descriptive research aimed to describe exactly the characteristics of an individual, condition, phenomenon, or certain groups within community [11]. It became the object of problem in the arrangement of 1945 Constitution (UUD 1945), Law No. 23 of 2014 about Local Government, Law No.12 of 2011 about Legislation, and Minister's Regulation Number 10 of 2011 about the Right To Test or Trial.

\section{Discussion}

\subsection{Local Regulation Drafting Mechanism}

Perda is developed by Local Legislative Assembly (Dewan Perwakilan Rakyat Daerah, thereafter called DPRD) at provincial level and approved by Governor. In Aceh, the Provincial Local Regulation is called Qanun, while in Papua and Papua Barat (West Papua) it is called Special Local Regulation (Peraturan Daerah Khusus, thereafter called Perdasus) and Provincial Local Regulation (Peraturan Daerah Provinsi, thereafter called Perdasi). Considering the Article 1 clause 8 of Law Number 12 of 2011 about Legislation, Regency/City Local Regulation is the one developed by DPRD at Regency/City level and approved by Regent/Mayor [12].

The material contained in Provincial and Regency/City Local Regulation is all content materials in the attempt of organizing local autonomy, assistance duty, and accommodating special condition of local area and further elaboration of higher Legislations.

There are many types of local regulations stipulated by Local Government. Article 15 clause (1) of Law No.12 of 2011 mentions that the material about criminal stipulation can be contained in Law; Provincial Local Regulation; or Regency/City Local Regulation [13].

Article 15 clause (1) explains that Provincial and Regency/City Local Regulations can contain punishment threat of imprisonment or the one other than what is mentioned in clause (2) corresponding to what is governed in other legislations [14].

Perda (Local Regulation) as a form of legislation is a part of national legal system development. A good local regulation can be realized when it is supported with appropriate method and standard, fulfills the technical instruction of legislating, as governed in Law No.12 of 2011. The types of Local Regulation stipulated by Provincial and Regency/City Governments are, among others: Local Tax; Local Retribution; Local Area Spatial Layout; Local Income and Expense Budget; Local Medium-Term Program Plan; Local Government and other General Regulations [15].

Local Regulation is a legislating product of local government, consisting of Local Leader and DPRD. Article 242 of Law No.23 of 2004 about Local Government states that Draft Local Regulation that has been approved by DPRD and Local Leaders is delivered to DPRD's leader and local leader to be stipulated as Perda (Local Regulation), the delivery of Draft Local Regulation as mentioned in clause (1) is conducted within 3 days after the approval date. Governor obligatorily delivers Draft Provincial Local Regulation as mentioned in clause (2) to the Minister as lately as 3 days after it has been received from Provincial Legislative Assembly's leader to get Perda register number; Regent/Mayor obligatorily delivers Draft Regency/City Local Regulation as mentioned in clause (2) to the Governor as lately as 3 days after it has been received from Regency/City Legislative Assembly's leader to get Perda register number; Minister gives the register number of draft Provincial Local Regulation and governor as the 
representative of Central Government gives register number of draft Regency/City Local Regulation as lately as 7 days after the draft has been received; the draft Local Regulation that has gotten register number as mentioned in clause (5) is stipulated by local leader by signing it as lately as 30 days after the draft has been approved by DPRD and Local Leader. Local Leader does not sign the draft Local Regulation that has gotten register number as mentioned in clause (6), draft local regulation is legalized to be Local Regulation and enacted compulsorily in local gazettes.

The development of Local Regulation should contain at least 3 foundations: philosophical foundation related to the State foundation or ideology, sociological foundation related to empirical condition or reality living within society including need or demand the people deal with, people's predisposition and expectation, and juridical foundation related to the authority of developing, the compatibility of content type and material and certain procedure to higher legislations.

Article 236 of Law No.23 of 2014 about Local Government mentions that to implement Local Autonomy and Assistance Duty, the Region develops Local Regulation. Local Regulation, as mentioned in clause (1), is developed by DPRD and approved by Local Leader. Meanwhile, Local Regulation as mentioned in clause (1) contains the material of Local Autonomy and Assistance Duty implementation, and further elaboration of the higher legislation's stipulation.

\subsection{Local Regulation Cancellation Mechanism and Its Legal Consequence Based on Lex Superiori Derogat Legi Inferiori principle in Economy}

Many local regulations are cancelled in 2016 related to investment factor thereby inhibiting economic factor in Indonesia. It is far from the program issued by government. To improve economy, Interior Ministry trims thousands Local Regulation existing in Indonesia.

Nowadays, the trial leading to the cancellation of Local Regulation has been conducted through Supreme Court's supervision or called Judicial Review. It is based on the previous argument stating that "Judicial review was the institutional capacity of the courts to determine the constitutional validity of the legal action taken by coordinates or lower than the branches of Government. It is a development from an effort to limit the powers of those who are authorized to interpret the sacred texts and secular, and to ensure that legislation, and actions they are empowered to enforce them will be consistent with the basic values of society and set the basic structure" [16].

Those Local Regulations were cancelled because they are in contradiction with the Provision of Higher Legislations. In drafting Local Regulations, legislators and drafters may not formulate a provision of Local Regulation as freely as possible. They should consider the higher legislations, such as 1945 Constitution, Law, Government Regulation, and Presidential Regulation. It is consistent with the lex superiori derogat legi inferiori legal principle, meaning that when there is a difference of governance, the provision of higher legislations disables that of lower legislations. Thus, Local Regulation is voided when it is in contradiction with the higher regulation as aforementioned [17].

In contradiction with public interest, the Local Regulation to be enacted may not harm the concord between members of society, the access to public service, the public composure and orderliness, and economic activity to improve the people's wellbeing, and/or may not result in discrimination against ethnic, religion and belief, race, betweengroups, and gender [17].

In contradiction with morality, the Local Regulation to be enacted may not be in contradiction with the norms related to courtesy and decorum, behavior, and people's etiquette where it is enacted. Not all of these local regulation cancellations contain 
cancellation element completely. Considering the Law No.23 of 2014 about Local Government, local policy in the form of Local Regulation can be cancelled by Interior Ministry either completely or only some articles [17].

Article 251 of Law No.23 of 2014 about Local Government mentions that Provincial Local and Governor Regulations in contradiction with the provision of higher legislation, public interest, and/or morality are cancelled by Minister. Regency/City Local Regulation and Regent/Mayor Regulation in contradiction with the provision of higher legislation, public interest, and/or morality are cancelled by Governor as the Representative of Central Government. In the case of Governor as the representative of Central Government not cancelling the Regency/City Local Regulation and Regent/Mayor Regulation in contradiction with the provision of higher legislation, public interest, and/or morality as mentioned in clause (2), the Minister cancels those regulations. The cancellation of Provincial Local and Governor Regulations as mentioned in clause (2) is stipulated with Minister's Decree and the cancellation of Regency/City Local Regulation and Regent/Mayor Regulation as mentioned in clause (2) is stipulated with governor's decree as the representative of Central Government [17].

To the Local Regulation cancelled, the local leader should stop the implementation of Local regulation and then along with DPRD should withdraw the Local Regulation intended as lately as 7 days after the cancellation decision. Meanwhile, to Perkada (Local Leader Regulation) cancelled, the local leader should stop the implementation of Perkada and then withdraw it as lately as 7 days after the cancellation decision.

When DPRD and Provincial Local Government cannot receive the decision of cancelling provincial Local Regulation and governor cannot receive the decision of cancelling Governor Regulation, Governor can file an objection to President as lately as 14 days since the decision of canceling Local Regulation received. Meanwhile, in the case of DPRD and Regency/City Local Government cannot receive the decision of cancelling Regency/City Local Regulation and Regent/Mayor cannot receive the decision of cancelling Regent/Mayor Regulation, Regent/Mayor can file an objection to Minister as lately as 14 days since the decision of canceling Local Regulation received.

DPRD and Provincial Local Government that still enact the Local Regulation cancelled by Minister or governor can be imposed with administrative sanction; and/or sanction of Draft Local Regulation evaluation postponement. Administrative sanction is imposed to local leaders and members of DPRD in the form of financial right nonpayment for 3 months. Sanction is not imposed when DPRD and local government still files objection to President for Provincial and to Minister for Regency/City Local Regulations.

Local Regulation trial conducted by government or in regulation trial study (toetzingrecht) is called executive review, resulting from the authority of central government's supervision over local autonomy organization. Local autonomy is the manifestation of democracy in the context of unitary state (eenheidstaat), not only meaning the presence of political decentralization (staatskundge entralisatie) generating the local authority to develop its own legislation (zelfwetgeving) but also enabling the region to run its own government (zelfbestuur), so that it can be said that the region runs its own household (eign huishouding) [17].

Executive review is any form of legal product from executives trialed by hierarchic institution and authority. In this context, "internal control", conducted internally over legal product issued in the form of both regeling and beschikking, is introduced; if normative control is conducted by outsiders, in this case State Administration Court, it is called legal control rather than executive review.

The object of "executive review" is the verdict that is abstract in nature and governs and binds generally or called regelling. And those beyond it or called "beschikking" 
becomes the legal object of State Administration Court. Either internal or external law precedent example is considered as important, because the government's task is closely related to State Administration's action undertaken by government organs and one of which is government. As we know, the government task (in broad definition), in addition to implementing the law, also pertains to the public service and the improvement of people's wellbeing [17].

In relation to "executive review", the object is regulation belonging to releging category conducted through withdrawing or cancelling certain regulations incompatible to the norm of law. This internal trial in the sense of "executive review" is conducted to keep the regulations developed by government (executives) synchronous and consistent viewed from its normative aspect vertically, and to maintain law orderliness and certainty in order to fulfill the people's feeling of justice or the social-economic change.

\section{Conclusion}

Stakeholders, including Local Leaders and DPRD, should study first any academic text of Local Regulation that will be Local Regulation. Thus, the purpose and objective of Local Regulation release is not in contradiction with the higher legislations. So many Local Regulations cancelled indicate that local governments, either executives or legislatives, are imprecise and inefficient.

People and those harmed with the presence of Local Regulation should see clearly rather than emphasize on their personal interest and override public interest. Fundamental points of a provision that can void local regulation should be the main reference by emphasizing on mutual benefit. Never void Local regulation because of certain groups' interest or profit-oriented personal interest.

\section{References}

1. Agustino, L. Politik Lokal dan Otonomi Daerah. Bandung: Alfabeta. (2014)

2. J. Asshidiqie, Model-Model Pengujian Konstitusional di Berbagai Negara, Konstitusi Press, Jakarta, (2000)

3. S. Salsabila, Skripsi Pengujian Peraturan Daerah oleh Cabang kekuasaan Eksekutif Pasca Putusan mahkamah Konstitusi nomor 137/PUU-XIII/2015 \& nomor 56/PUUXIV/2016, (Universitas Gajah Mada, Fakultas Hukum, 2017)

4. http://warta.co/ketua-mpr-sepakat-pembatalan-perda-oleh-pemerintah.html 26 April (2018)

5. S. Deakin, D. Gindis, Geoffrey, M. Hodgson, H. Kainan, K. Pistor, Journal of Comparative Economics Legal institutionalism: Capitalism and the constitutive role of law Volume 45, Issue 1, February (2017)

6. R. Miranda, Mexican Law Review, The Becoming-Other Of Law: Preliminaries For A citizen"s Conceptualization Of Law, Volume 8, Issue 2, January-June, (2016)

7. Constitution Court' Verdict Number 137/PUU-XII/2015 about the Trial of Law Number of 23 of 2014 about Local Government)

8. A. Keogh, Encyclopedia of Forensic and Legal Medicine (Second Edition), Court Systems: Legal Precedent and Case Law (2016)

9. S. Soekanto, Pengantar Penelitian Hukum. (UI Press, Jakarta, 2006)

10. Setiono, Pemahaman Terhadap Metodologi Penelitian Hukum, Program Studi Ilmu Hukum Pascasarjana Universitas Sebelas Maret, Surakarta, (2005) 
11. S. Soekanto, Pengantar Penelitian Hukum, Ctk. Ketiga, Jakarta, Universitas Indonesia (UI-Press, 1986)

12. L. Marzuki. Berjalan-jalan di Rumah Hukum, Setjen MK, Jakarta, Paulus Effendi Lotulung, Laporan Akhir dan Evaluasi Hukum tentang Wewenang Mahkamah Agung dalam Melaksanakan Hak Uji Materil (judicial review), Jakarta Badan Pembinaan Hukum-Departemen Hukum, Perundang-Undangan RI Tahun 1999/2000. (2006)

13. Undang-undang Nomor 12 Tahun 2011 Tentang Pembentukan Peraturan Perundangundangan (Law Number 12 of 2011 about Legislations).

14. S. Wiyono and K. Goesniadhie S. Kekuasaan Kehakiman Pasca Prubahan UUD 1945, Penerbit : Universitas Negeri Malang (UM Press) (2007)

15. S. Nugraha, Hukum Administrasi Negara, Jakarta, Badan Penerbit : Fakultas Hukum Universitas Indonesia (UI), (2005)

16. J.B.Grossman, International Encyclopedia of the Social \& Behavioral Sciences, Judicial Review in Law, (2001)

17. Y. Pattinasarany, Kewenangan Pembatalan Peraturan Daerah, Jurnal sasi Vo.17 No.4 Oktober-Desember, (2011)

\section{Regulation}

1. 1945 Constitution

2. Law Number 23 Year 2014 concerning Local Government

3. Law Number 13 Year 2003 concerning Manpower

4. West Java Provincial Local Regulation Number 6 Year 2014 concerning Manpower Organization

5. Constitution Court's Verdict No. 56/PUU-XIV/2016 concerning the Trial of Law Number of Minister Regulation Number 10 Year 2011 concerning the Right to Trial 